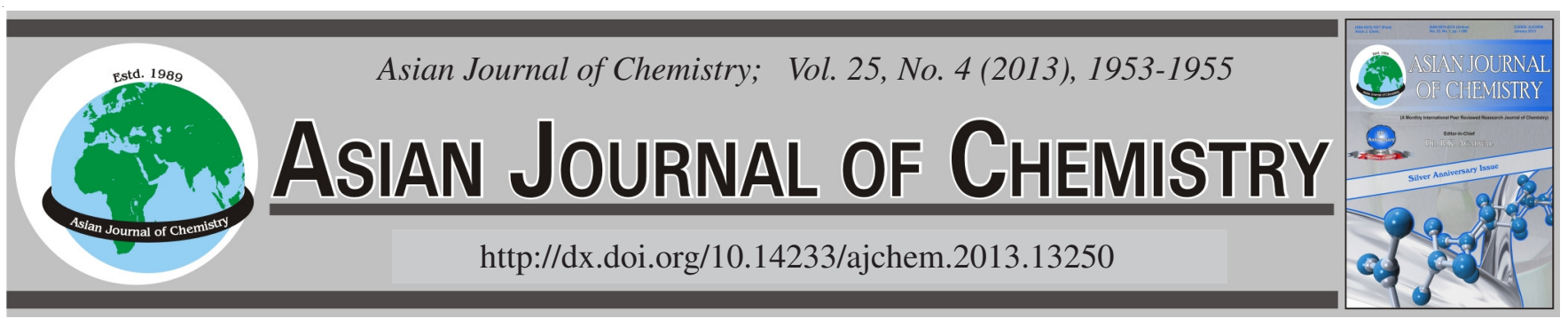

\title{
Synthesis and Crystal Structure of Hexaaquamagnesium(II) Bis(N-p-tolysulfonyl-glycinate) Dihydrate
}

\author{
TAI XI-ShI ${ }^{*}$, WANG Dong and TANG NA
}

College of Chemistry and Chemical Engineering, Weifang University, Weifang 261061, P.R. China

*Corresponding author: Fax: +86 536 8785363; Tel: +86536 8785363; E-mail: taixs@wfu.edu.cn

\begin{abstract}
A new coordination compound of magnesium(II) $\left[\mathrm{Mg}\left(\mathrm{H}_{2} \mathrm{O}\right)_{6}\right] \cdot(\mathrm{L})_{2} \cdot\left(\mathrm{H}_{2} \mathrm{O}\right)_{2}[\mathrm{~L}=\mathrm{N}-\mathrm{p}$-tolysulfonyl-glycinate $]$ was synthesized by the reaction of magnesium chloride hexahydrate with $\mathrm{N}$ - $p$-tolysulfonyl-glycine in the $\mathrm{CH}_{3} \mathrm{CH}_{2} \mathrm{OH} / \mathrm{H}_{2} \mathrm{O}$ (v:v = 5:1). It was characterized by elemental analysis, IR and X-ray single crystal diffraction analysis. The crystal of the present coordination compound $\left[\mathrm{Mg}\left(\mathrm{H}_{2} \mathrm{O}\right)_{6}\right] \cdot(\mathrm{L})_{2} \cdot\left(\mathrm{H}_{2} \mathrm{O}\right)_{2}$ belongs to triclinic, space group P-1 with $\mathrm{a}=0.57192(11) \mathrm{nm}, \mathrm{b}=0.57717(12) \mathrm{nm}, \mathrm{c}=2.2564(5) \mathrm{nm}, \alpha=91.90(3)^{\circ}, \beta=96.28(3)^{\circ}, \gamma=$ $104.04(3)^{\circ}, V=0.7168(2) \mathrm{nm}^{3}, Z=1, D_{c}=1.448 \mathrm{Mg} \mathrm{m}^{-3}, \mu=0.281 \mathrm{~mm}^{-1}, F_{(000)}=330$ and final $R_{1}=0.0668$, w $R_{2}=0.1863$. The complex comprises a six-coordinated magnesium(II) center, with a $\mathrm{O}_{6}$ distorted octahedron coordination environment. The molecules are connected by hydrogen bonds and $\pi-\pi$ stacking to form one dimensional chain structure.
\end{abstract}

Key Words: N-p-Tolysulfonyl-glycine, Mg(II) complex, Synthesis, Crystal structure.

ᄂ - - - - - - - - - - - - - - - - - - - - - - - - - - - -

\section{INTRODUCTION}

The design and synthesis of metal complexes with carboxylate ligands have attracted intense attention in recent years owing to their potential practical applications, such as molecule-based magnets, luminescence, biological properties ${ }^{1-3}$. Transition metal complexes with carboxylate ligands have been extensively investigated ${ }^{4-6}$. To the best of our knowledge, the magnesium(II) complexes with carboxylate ligands have been much less extensively studied than other complexes. In this paper, we report the synthesi and X-ray crystal structure of $\left[\mathrm{Mg}\left(\mathrm{H}_{2} \mathrm{O}\right)_{6}\right] \cdot(\mathrm{L})_{2} \cdot\left(\mathrm{H}_{2} \mathrm{O}\right)_{2}[\mathrm{~L}=\mathrm{N}$-p-tolysulfonyl-glycinate $]$.

\section{EXPERIMENTAL}

The following A.R. grade chemicals were used for the preparation of the studied compound: magnesium chloride hexahydrate, $p$-tolysulfonyl chloride, glycine, sodium hydroxide.

The carbon, hydrogen and nitrogen content in the newly synthesized compound were determined on a Elementar Vario III EL elemental analyzer. Infrared spectrum (4000-400 $\mathrm{cm}^{-1}$ ) was recorded with KBr optics on a Nicolet AVATAR 360 FTIR spectrophotometer. The crystal data was collected on a Bruker smart CCD Area Detector.

Synthesis of the ligand: $10 \mathrm{mmol}(0.7507 \mathrm{~g})$ of glycine and $20 \mathrm{mmol}(0.8 \mathrm{~g})$ of sodium hydroxide were dissolved in $100 \mathrm{~mL}$ of water at room temperature and added drop by drop
$10 \mathrm{mmol}$ (1.9065 g) of $p$-tolysulfonyl chloride by stirring at room temperature. The reaction solution was kept running for $4 \mathrm{~h}$, then acidified with the solution of hydrochloric acid (v:v $=1: 1)$ to $\mathrm{pH}=2$. The white solid precipitation were collected by filtration, washed and dried under vacuum. Yield may reach up to over $65 \%$. Elementary analysis: calcd. (\%) for $\mathrm{C}_{9} \mathrm{H}_{11} \mathrm{NSO}_{4}$ : C, 47.16; H, 4.80; N, 6.11; found (\%): C, 47.58; $\mathrm{H}, 4.52 ; \mathrm{N}, 6.39$. IR $\left(\mathrm{KBr}, \mathrm{v}_{\max }, \mathrm{cm}^{-1}\right):(\mathrm{C}=\mathrm{O}): 1719,1436$, (N-H): 3248.

Synthesis of $\mathbf{M g}$ (II) complex: $1.0 \mathrm{mmol}(0.229 \mathrm{~g})$ of $\mathrm{N}$-p-tolysulfonyl-glycine and $1.0 \mathrm{mmol}(0.04 \mathrm{~g})$ of sodium hydroxide were added to the $10 \mathrm{~mL}$ of $\mathrm{CH}_{3} \mathrm{CH}_{2} \mathrm{OH} / \mathrm{H}_{2} \mathrm{O}$ (v:v $=5: 1)$ solution. After being dissolved, $0.5 \mathrm{mmol}(0.1015 \mathrm{~g})$ of magnesium chloride hexahydrate was added to the solution. The mixture was continuously stirred for $3 \mathrm{~h}$ at refluxing temperature. The mixture was cooled at room temperature and was collected by filtration. By evaporation in air at room temperature, the single crystal suitable for X-ray determination was obtained from methanol solution after 7 days. Yield: 56 $\%$. Elementary analysis: calcd. (\%) for $\mathrm{C}_{18} \mathrm{H}_{36} \mathrm{~N}_{2} \mathrm{O}_{16} \mathrm{~S}_{2} \mathrm{Mg}$ : C, 34.62; H, 5.77; N, 4.49; found (\%): C, 34.58; H, 5.69; N, 4.72. IR $\left(\mathrm{KBr}, \mathrm{v}_{\max }, \mathrm{cm}^{-1}\right):(\mathrm{C}=\mathrm{O}): 1718,1435,(\mathrm{~N}-\mathrm{H}): 3247,\left(\mathrm{H}_{2} \mathrm{O}\right)$ : 3423, (Mg-O): 423.

X-Ray crystallography: A colourless block single crystal was placed on a glass fiber and mounted on a CCD area detector. Diffraction data were collected by $\varphi \sim \omega$ scan mode using a graphite-monochromatic $\operatorname{MoK}_{\alpha}$ radiation $(\lambda=0.71073$ 
$\AA$ ) at 293 (2) K. A total of 5430 reflections were collected in the range $3064-25.00^{\circ}$, of which 2503 were unique $\left(R_{\text {int }}=\right.$ 0.049 ) and 1900 were observed with $\mathrm{I}>2 \sigma(\mathrm{I})$. The data were corrected for Lp factors. The structure was solved by direct methods and refined by full-matrix least-squares techniques on $\mathrm{F}^{2}$. The structure was solved by direct methods ${ }^{7}$ using SHELXL-97 and expanded using Fourier techniques. All nonhydrogen atoms and hydrogen atoms were refined anisotropically and isotropically, respectively. The final refinement by full-matrix least squares method was converged at $\mathrm{R}=0.0668$ and $w R=0.1863\left(\mathrm{w}=1 /\left[\delta^{2}\left(\mathrm{Fo}^{2}\right)+(0.1209 \mathrm{P})^{2}+0.0218 \mathrm{P}\right], \mathrm{P}\right.$ $\left.=\left(\mathrm{Fo}^{2}+2 \mathrm{Fc}^{2}\right) / 3, \mathrm{~S}=1.104,(\Delta / \sigma)_{\max }=0.001\right)$. The largest peak in the final difference Fourier map is $0.466 \mathrm{e} / \AA^{3}$ and the minimum peak is $-0.511 \mathrm{e} / \AA^{3}$. Molecular graphics were drawn with the program package SHELXTL-97 crystallographic software package ${ }^{8}$. The most relevant crystal data for complex are quoted in Table-1 and the selected bond distances and angles are listed in Table-2.

\begin{tabular}{|c|c|}
\hline \multicolumn{2}{|c|}{$\begin{array}{c}\text { TABLE-1 } \\
\text { CRYSTALLOGRAPHIC DATA FOR Mg(II) COMPLEX }\end{array}$} \\
\hline Formula & $\mathrm{C}_{18} \mathrm{H}_{36} \mathrm{MgN}_{2} \mathrm{O}_{16} \mathrm{~S}_{2}$ \\
\hline Formula weight & 624.92 \\
\hline Crystal system & Triclinic \\
\hline Space group & $\mathrm{P}-1$ \\
\hline $\mathrm{a}(\AA)$ & $5.7192(11)$ \\
\hline b $(\AA)$ & $5.7717(12)$ \\
\hline c $(\AA)$ & $22.564(5)$ \\
\hline$\alpha\left(^{\circ}\right)$ & $91.90(3)$ \\
\hline$\beta\left({ }^{\circ}\right)$ & $96.28(3)$ \\
\hline$\gamma\left({ }^{\circ}\right)$ & 104.04(3) \\
\hline $\mathrm{Z}$ & 1 \\
\hline$F_{(000)}$ & 330 \\
\hline Temperature (K) & $293(2)$ \\
\hline $\mathrm{V}\left(\AA^{3}\right)$ & $716.8(2)$ \\
\hline Calculated density $\left(\mathrm{g} \mathrm{cm}^{-3}\right)$ & 1.448 \\
\hline$\mu\left(\mathrm{mm}^{-1}\right)$ & 0.281 \\
\hline Limiting indices & $-6 \leq \mathrm{h} \leq 6,-6 \leq \mathrm{k} \leq 6,-26 \leq 1 \leq 26$ \\
\hline Reflections collected/unique & $5430 / 2503$ \\
\hline $\mathrm{R}_{1}$, w $\mathrm{R}_{2}$ [all data] & $0.0788,0.1981$ \\
\hline $\mathrm{R}_{1}, \mathrm{wR}_{2}[\mathrm{I}>2 \sigma(\mathrm{I})]$ & $0.0668,0.1863$ \\
\hline Largest diff. peak and hole $\left(\mathrm{e} \AA^{-3}\right)$ & $0.466,-0.511$ \\
\hline
\end{tabular}

\section{RESULTS AND DISCUSSION}

In the infrared spectra, the $v(\mathrm{COOH})$ vibrations of the free ligand are at 1719 and $1436 \mathrm{~cm}^{-1}$. For the complex, the vibration observed at $1718 \mathrm{~cm}^{-1}$ is assigned as $\mathrm{v}_{\text {as }}\left(\mathrm{COO}^{-}\right)$and that at $1435 \mathrm{~cm}^{-1}$ as $\mathrm{v}_{\mathrm{s}}\left(\mathrm{COO}^{-}\right)$. Which indicate that the carboxylate oxygen atoms of N-p-tolysulfonyl-glycinate ligand do not involve in the coordination with magnesium atoms ${ }^{9}$. The bands of the $-\mathrm{SO}_{2}-\mathrm{NH}$ - groups at 3248,1320 and $1155 \mathrm{~cm}^{-1}$ show that there are uncoordinated atoms of the groups, because compared with the free ligand the strong absorption bands are not shifted. The new IR band appearing at $423 \mathrm{~cm}^{-1}$ is assigned to $\mathrm{v}(\mathrm{Mg}-\mathrm{O})$ vibration. In addition, the band at $3423 \mathrm{~cm}^{-1}$ shows that the complex contains water molecules, which are accordance with the results of elemental analysis.

Structure description: Perspective view of the molecule in a unit cell and molecular packing arrangement are shown in Figs. 1 and 2, respectively. It can be seen that the coordination

\begin{tabular}{|c|c|c|c|}
\hline \multicolumn{4}{|c|}{$\begin{array}{c}\text { TABLE-2 } \\
\text { SELECTED BOND LENGTHS (̊̊) AND } \\
\text { ANGLES }\left(^{\circ}\right) \text { FOR Mg(II) COMPLEX }\end{array}$} \\
\hline $\mathrm{Mg} 1-\mathrm{O} 2 \mathrm{~W}$ & $1.938(2)$ & S1-O3 & $1.393(3)$ \\
\hline $\mathrm{Mg} 1-\mathrm{O} 2 \mathrm{~W}^{\mathrm{i}}$ & $1.938(2)$ & S1-O4 & $1.429(3)$ \\
\hline $\mathrm{Mg} 1-\mathrm{O} 1 \mathrm{~W}^{\mathrm{i}}$ & $2.052(2)$ & S1-N1 & 1.499 (3) \\
\hline Mg1-O1W & $2.052(2)$ & S1-C3 & $1.916(4)$ \\
\hline Mg1-O3W & $2.191(2)$ & $\mathrm{O} 2-\mathrm{C} 1$ & $1.307(5)$ \\
\hline $\mathrm{Mg} 1-\mathrm{O} 3 \mathrm{~W}^{\mathrm{i}}$ & $2.191(2)$ & N1-C2 & $1.444(5)$ \\
\hline $\mathrm{O} 2 \mathrm{~W}-\mathrm{Mg} 1-\mathrm{O} 2 \mathrm{~W}^{\mathrm{i}}$ & $180.00(13)$ & $\mathrm{O} 1 \mathrm{~W}^{\mathrm{i}}-\mathrm{Mg} 1-\mathrm{O} 3 \mathrm{~W}^{\mathrm{i}}$ & $85.12(10)$ \\
\hline $\mathrm{O} 2 \mathrm{~W}-\mathrm{Mg} 1-\mathrm{O} 1 \mathrm{~W}^{\mathrm{i}}$ & 90.45 (11) & O1W-Mg1-O3W & $94.88(10)$ \\
\hline $\mathrm{O} 2 \mathrm{~W}^{\mathrm{i}}-\mathrm{Mg} 1-\mathrm{O} 1 \mathrm{~W}^{\mathrm{i}}$ & $89.55(11)$ & O3W-Mg1-O3W & $180.00(2)$ \\
\hline O2W-Mg1-O1W & $89.55(11)$ & $\mathrm{O} 3-\mathrm{S} 1-\mathrm{O} 4$ & $121.3(2)$ \\
\hline $\mathrm{O} 2 \mathrm{~W}^{\mathrm{i}}-\mathrm{Mg} 1-\mathrm{O} 1 \mathrm{~W}$ & $90.45(11)$ & O3-S1-N1 & $101.13(19)$ \\
\hline O1W'-Mg1-O1W & $180.00(1)$ & O4-S1-N1 & $105.16(17)$ \\
\hline $\mathrm{O} 2 \mathrm{~W}-\mathrm{Mg} 1-\mathrm{O} 3 \mathrm{~W}$ & $94.56(10)$ & O3-S1-C3 & $110.96(18)$ \\
\hline $\mathrm{O} 2 \mathrm{~W}^{\mathrm{i}}-\mathrm{Mg} 1-\mathrm{O} 3 \mathrm{~W}$ & $85.44(10)$ & O4-S1-C3 & $106.97(17)$ \\
\hline O1W'-Mg1-O3W & $94.88(10)$ & N1-S1-C3 & 110.85 (17) \\
\hline O1W-Mg1-O3W & $85.12(10)$ & C2-N1-S1 & $117.1(3)$ \\
\hline $\mathrm{O} 2 \mathrm{~W}-\mathrm{Mg} 1-\mathrm{O} 3 \mathrm{~W}^{\mathrm{i}}$ & $85.44(10)$ & $\mathrm{O} 1-\mathrm{C} 1-\mathrm{O} 2$ & $123.9(3)$ \\
\hline $\mathrm{O} 2 \mathrm{~W}^{\mathrm{i}}-\mathrm{Mg} 1-\mathrm{O} 3 \mathrm{~W}^{\mathrm{i}}$ & $94.56(10)$ & $\mathrm{O} 1-\mathrm{C} 1-\mathrm{C} 2$ & $110.8(4)$ \\
\hline $\mathrm{N} 1-\mathrm{C} 2-\mathrm{C} 1$ & $109.9(3)$ & $\mathrm{O} 2-\mathrm{C} 1-\mathrm{C} 2$ & $125.3(3)$ \\
\hline
\end{tabular}

Symmetry codes: (i) $-\mathrm{x},-\mathrm{y},-\mathrm{z}+2$.

environment of the $\mathrm{Mg}(\mathrm{II})$ atom consists of six oxygen atoms from the coordinated water molecules, making up a distorted octahedral environment. In the complex molecule, the $\mathrm{N}$ - $p$-tolysulfonyl-glycinates do not take part in coordination with $\mathrm{Mg}(\mathrm{II})$, they exists in the molecules through intramolecule and intermolecule hydrogen bonds. The hydrogen bonds between the oxygen atoms of $\mathrm{N}$ - $p$-tolysulfonyl-glycinate and the oxygen atoms of coordinated water molecules are as following: $\mathrm{O}(1 \mathrm{~W})-\mathrm{H}(1 \mathrm{WA}) \cdots \mathrm{O}(2)[0.2864(4) \mathrm{nm}$,

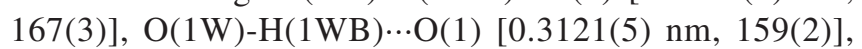
$\mathrm{O}(1 \mathrm{~W})-\mathrm{H}(1 \mathrm{WB}) \cdots \mathrm{O}(2)$ [0.2987(4) nm, 113(3)], O(2W)$\mathrm{H}(2 \mathrm{WA}) \cdots \mathrm{O}(1) \quad[0.2642(4) \mathrm{nm}, \quad 170(4)], \quad \mathrm{O}(2 \mathrm{~W})-$ $\mathrm{H}(2 \mathrm{WB}) \cdots \mathrm{O}(2)[0.2931(4) \mathrm{nm}, 107(3)]$ and $\mathrm{O}(3 \mathrm{~W})-$ $\mathrm{H}(3 \mathrm{WA}) \cdots \mathrm{O}(2)[0.2822(4) \mathrm{nm}, 168(3)]$, the distances of the $\mathrm{Mg}(1)-\mathrm{O}$ bonds are in the range of 1.938 (2)-2.191 (2) $\AA$, which are similar to the $\mathrm{Mg}-\mathrm{O}$ bond lengths reported previously $^{10}$.

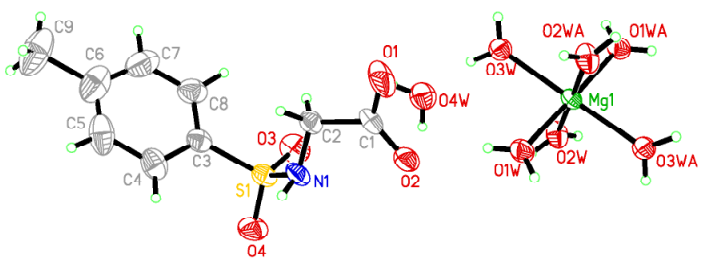

Fig. 1. Molecular structure of the complex

The complex forms one dimensional chain structure by intramolecule and intermolecule hydrogen bonds and $\pi-\pi$ stacking (Fig. 3).

\section{Conclusion}

In summary, a new complex $\left[\mathrm{Mg}\left(\mathrm{H}_{2} \mathrm{O}\right)_{6}\right] \cdot(\mathrm{L})_{2} \cdot\left(\mathrm{H}_{2} \mathrm{O}\right)_{2}[\mathrm{~L}$ $=\mathrm{N}$ - $p$-tolysulfonyl-glycinate] was synthesized and structurally characterized. The complex comprises a six-coordinated magnesium(II) center, with a $\mathrm{O}_{6}$ distorted octahedron coordination environment. The molecules are connected by hydrogen bonds and $\pi-\pi$ stacking to form one dimensional chain structure. 


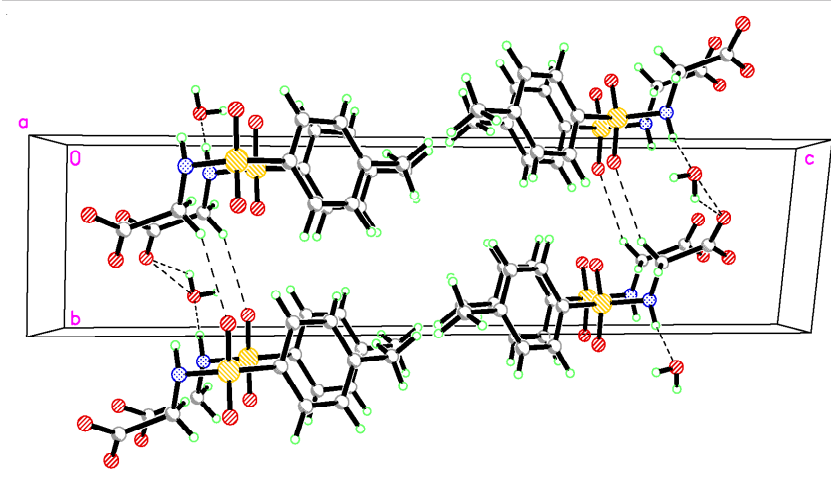

Fig. 2. Molecular packing arrangement

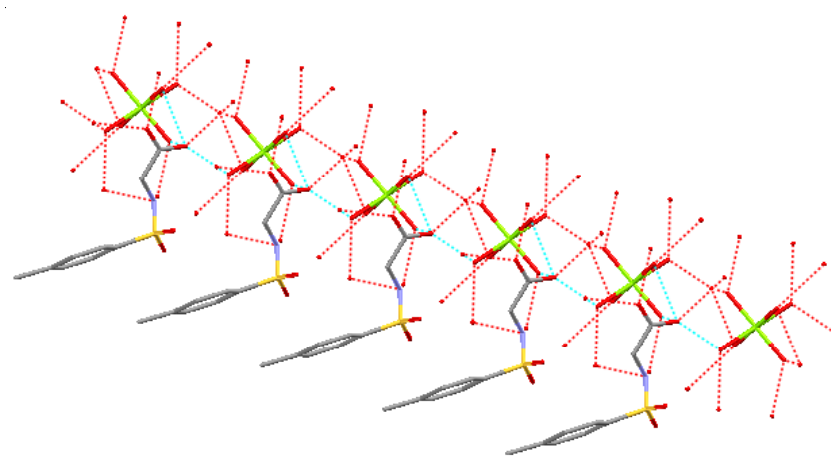

Fig. 3. One dimensional chain of the complex

\section{ACKNOWLEDGEMENTS}

The authors thank the National Natural Science Foundation of China (No. 21171132 and 20671073), the Promotive Research Fund for Excellent Young and Middle-Aged Scientists of Shandong Province (2010BSA07004) and Science Foundation of Weifang University.

\section{REFERENCES}

1. W.G. Lu, L. Jiang, X.L. Feng and T.B. Lu, Cryst. Growth Des., 6, 564 (2006)

2. L.J. Tian, H.J. Yang, X.L. Zheng, Z.H. Ni, D.M. Yan, L.L. Tu and J.Z. Jiang, Appl. Organomet. Chem., 23, 24 (2009).

3. L.F. Wang, Y.X. Hu, W.W. Zhang and X.M. Ren, Chin. J. Inorg. Chem., 27, 542 (2011).

4. O.R. Evans, R.G. Xiong, Z. Wang, G.K. Wong and W.B. Lin, Angew. Chem., Int. Ed. Engl., 38, 536 (1999).

5. S.K. Ghosh, G. Savitha and P.K. Bharadwaj, Inorg. Biochem., 43, 5945 (2004).

6. R. Garcia-Zarracino and H. Hopfl, J. Am. Chem. Soc., 127, 3120 (2005).

7. G.M. Sheldrick, SHELXL-97, Program for Crystal Structure Solution; University of Gottingen: GÖttingen, Germany (1997).

8. G.M. Sheldrick, SHELXTL-97, Program for Crystal Structure Refinement; University of Gottingen: Gottingen, Germany (1997).

9. K. Nakamoto, Infrared and Ramen Spectra of Inorganic and Coordination Compounds, New York: John Wiley \& Sons, edn. 3 (1978).

10. X.S. Tai, L.C. Du and Z.B. Zeng, Chin. J. Inorg. Chem., 27, 575 (2011). 